\title{
STATISTICAL ANALYSIS OF PASSENGER TRAFFIC AT THE CHOPIN AIRPORT
}

DATA PRZESŁANIA: 10.12.2015|DATA AKCEPTACJI: 12.12.2015 | JEL CODE: C40

\section{PhD Justyna Tomaszewska}

Wydział Bezpieczeństwa Narodowego i Logistyki, WSOSP, Dęblin, Polska

e-mail: j.tomaszewska@wsosp.pl

In the article, the selected directions of passenger traffic at the largest Polish airport, Frederic Chopin Airport located in Warsaw, are presented. Statistical analysis has been used to present the main routes of movement of people and showing the trends of changes. It was observed that in order to obtain more accurate analysis, different trends per month have to be taken into account, because of the popularity of the number of passengers which will affect the character of the place: tourist, business or business-tourism.

KEYWORDS

statistical analysis, passenger traffic, Frederic Chopin Airport in Poland, main routes of movement

\section{INTRODUCTION}

On April 29, 1934, Polish president Ignacy Mościcki opened the Polish Central Airport at Okęcie located at that time close to Warsaw and took over all air traffic from the former civilian aerodrome at Pole Mokotowskie. In the first year of operating, the port handled just over 10 thousand passengers. Currently, this number is three times higher, and on a daily basis! Nowadays, the Chopin Airport offers 108 destinations on three continents (Rocznica..., 2016). (Rocznica Lotniska Chopina - Aktualności i wydarzenia - Lotnisko Chopina w Warszawie, 2016). Among the directions that handled the largest number of passengers, there are: London, Paris and Frankfurt. Nevertheless, on the list of the top 10 there are also included two Polish cities, namely Kraków and Wrocław.

In order to develop this article, the number of passengers for 55 destinations was selected and analyzed, which constituted about 70 percent of all served passengers. The main goal of this 
article is to present the trends that can be observed only by using statistical methods. The author does not intend to interpret them from the point of view of the circumstances that caused them. In the paper, the general changes in annual and monthly terms between 2004 and 2014 are presented. Additionally, the examples of supported directions are mentioned.

\section{STATISTICAL ANALYSIS}

\section{TIME SERIES}

Dynamic time series are one of the statistical models used to describe the changes as a function of time. A characteristic feature of this model is an explicit inclusion of the time factor. Typical dynamic models are divided into two groups: exogenous models and models with delayed variable. In the first one, the time variable corresponds to the next time periods (e.g. months) and is the only explanatory variable. Among them, there are distinguished models describing the trend of constant tendencies, for example, increasing or decreasing. Depending on describing data, this model takes various analytical forms including linear, exponential and logarithmic. On the one hand, to a great advantage of these models is that they are easy to interpret and determine the trend of changes, and on the other hand they do not describe the causal relationships between variables and do not take into account the sources of variation. The second group of dynamic models are the models with a delay of the explained variables, explanatory or both. These models are used when the explained resizing may be under the influence of another variable e.g. an increase in the number of passengers is due to organizing a sport event in the city. One of the major issues discussed regarding the time series is their stationarity, the degree of their integration in time and long-term co-integration and balance (Gruszczyński \& Podgórska, 2008).

\section{DATA}

The study is based on data available at the Eurostat website (Eurostat, 2016). Fifty-five of the main connections between the Chopin Airport and airports worldwide were selected, among which there were six airports in Poland, namely: Gdańsk, Katowice, Poznań, Kraków, Rzeszów, Szczecin. In the paper, the division into arriving and departing passengers, was not included assuming that their number is at a similar level. The number of served passengers analyzed in this article is approximately $70 \%$ of all served people.

\section{ANALYSIS}

\section{LINEAR REGRESSION}

Between 2004 and 2014, the Chopin Airport served more than 97 million people, however the number is much smaller than 753 million of passengers served at the Heathrow airport in London, but still it is comparable with such airports as Prague or Budapest. 


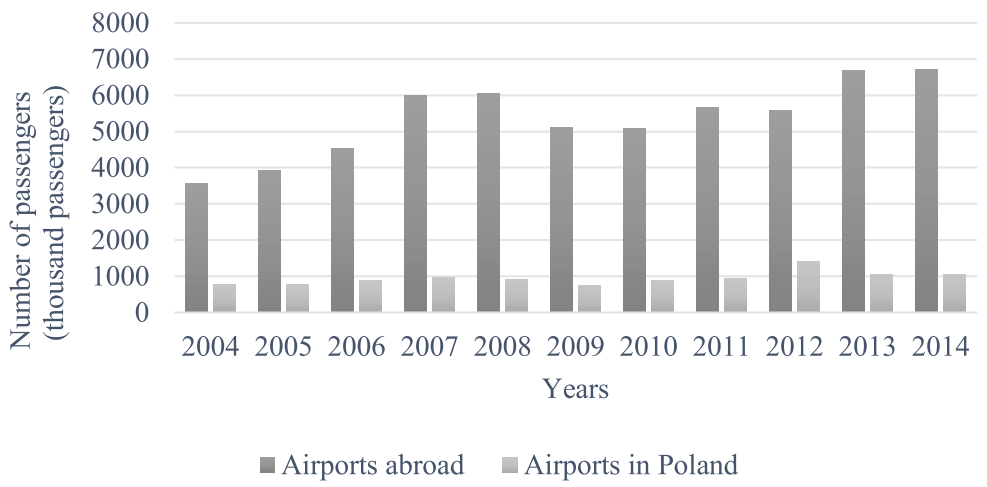

Figure 1. The number of passengers arriving or departing from the Chopin Airport in the years 2004-2014 Source: own calculations based on data from the Eurostat.

Figure 1 shows the number of passengers handled in the years 2004-2014 at the Chopin Airport in Warsaw. It can be concluded that the number of passengers will be increasing in subsequent years.

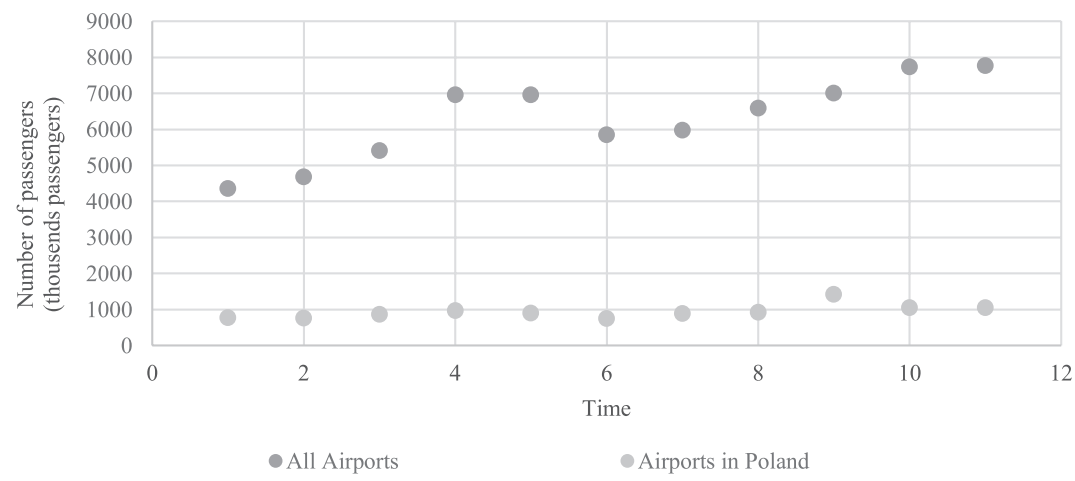

Figure 2. The number of the exchanged passengers with the prediction of linear trends. The numbers correspond to the years of 2004-2014

Source: own calculations based on data from Eurostat.

Figure 2 shows the number of exchanged passengers as a function of time. On the basis of figure 2, it can be observed that the number of passengers exchanged within foreign airports increases faster than the number of passengers in domestic traffic. This growth can be identified with fit of the regression linear model (Smith, 2010; Ptak-Chmielewska, 2013), which in this case has the following form:

the number of passengers handled $=266,61 \times \mathrm{t}+4792,60$ (for airports abroad) and the number of passengers handled $=37,11 \times t+724,14$ (for airports in Poland), where $t$ represents independent time variable. 
According to the fit, it can be concluded that an annual increase of the number of passengers is approximately 266 thousand in the case of international traffic and 37 thousand in the domestic one. It can be assumed that the growth of the number of passengers in the next years will be similar. Taking under consideration the values of determination $\mathrm{R}^{2}$, it can be assumed that on the level of 63 percent (42 percent for domestic flights) the increase in the number of passengers can be explained by linear trends. Additionally, the values of $\mathrm{t}$ - and p-statistics indicate that there is a significant linear relationship between the number of passengers and time. Despite the previous conclusions, the linear regression model should be excluded as a forecast mode in future, because the local interference is observed in a linear trend. This model fulfills the accepted assumption in the regression model with random distribution of residues which can also be observed in figure 2 . Some of the data in certain periods is consistently above or below the trend line. Moreover, an increase in the number of exchanged people on domestic flights in 2012 can also be seen, due to the UEFA European Football Championship.

\section{TIME SERIES WITH SEASONS TRENDS}

As mentioned previously, the linear model provides only very approximate predictions of the number of served passengers. In order to obtain more precise expectation, it is better to analyse data on a monthly basis. The data in monthly periods is presented in figure 3 .

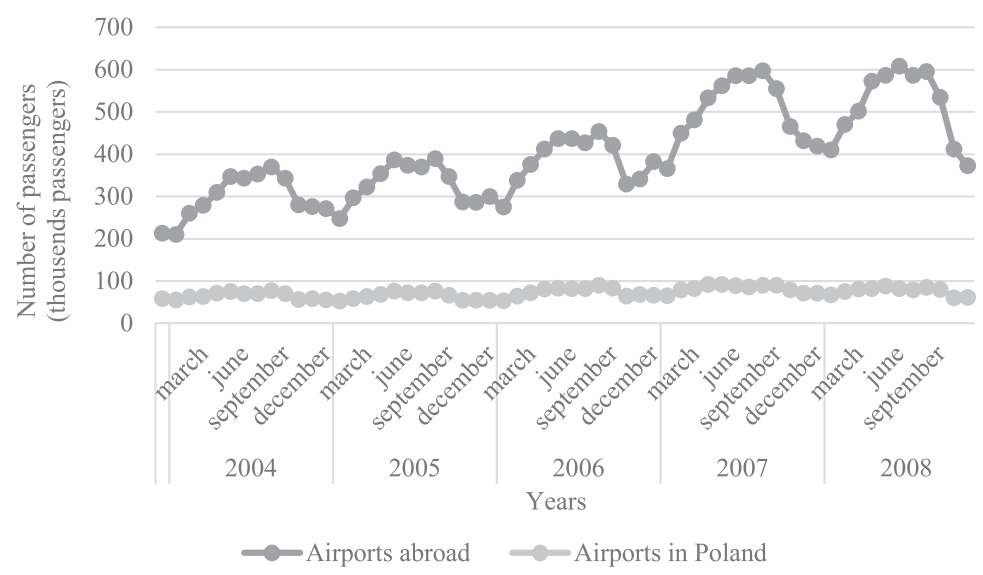

Figure 3. The number of passengers arriving or departing in the month terms from the Chopin Airport between 2004 and 2014. The upper figure shows the period 2004-2008, the lower one - 2009-2014

Source: own calculations based on data from Eurostat.

On the basis of figure 3, it can be noted that some data structures are repeated in a cyclic manner. In order to explain the structures, individual changes should be carefully examined. Figure 3 shows the number of passengers in summer months which is significantly higher than in the winter time. The maximum number of passengers during a year decreases in June and August. As can be seen in figure 3, the number of exchanged passengers by international flights in the month of August is smaller than the number in July and September. The largest 
decline in the number of people using airports can be noticed between October and November. The apparent increase can be also observed in March 2010. The higher value than in April was caused by the volcanic eruption that caused the cancellation of many connections.

For example, Poland, as well as most of other countries, closed the entire airspace (Wikipedia, 2010).

As mentioned previously, the aim of this article is to show the trends of changes, not the interpretation from a geopolitical point of view.

Figure 4 presents the determination of a ratio between the number of passengers handled at domestic flights to the number of passengers at international flights. The increase in the winter months and decrease in the summer months can be noted. It is caused by a large number of international flights during this period.

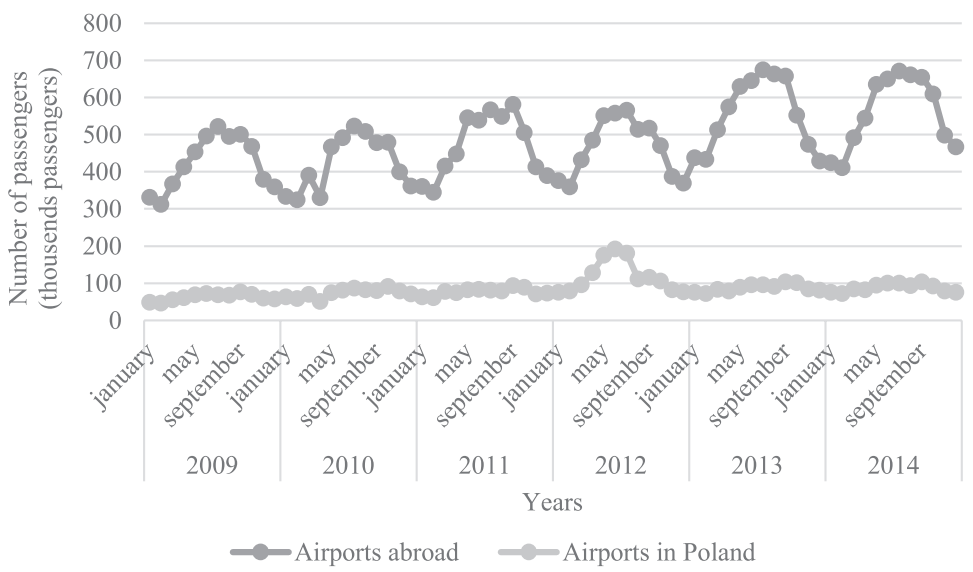

Figure 4. The ratio of the number of passengers in domestic traffic to the number of passengers carried in international traffic in the years 2004-2014

Source: own calculations based on data from Eurostat.

\section{CASE STUDY}

In order to better understand the changes of the number of passengers as a function of time, several specific cases were selected: three airports which take the largest exchange of passengers, four airports in Poland and two airports mainly for tourist traffic. The first group (fig. 5) is represented by airports: London - Heathrow, Frankfurt. Main, Charles de Gaulle in Paris. There are two out of top ten business cities in the world (CNBC, 2011). The average number of exchanged passengers for each of these airports per month is approximately 30 thousand. According to figure 5, it can be concluded that the number of passengers exchanged with the Heathrow airport changed in different years and that in 2008 it was over 10\%, which is 50\%-60\% lower than in the corresponding months of winter-fall 2007 and April-September, respectively. 


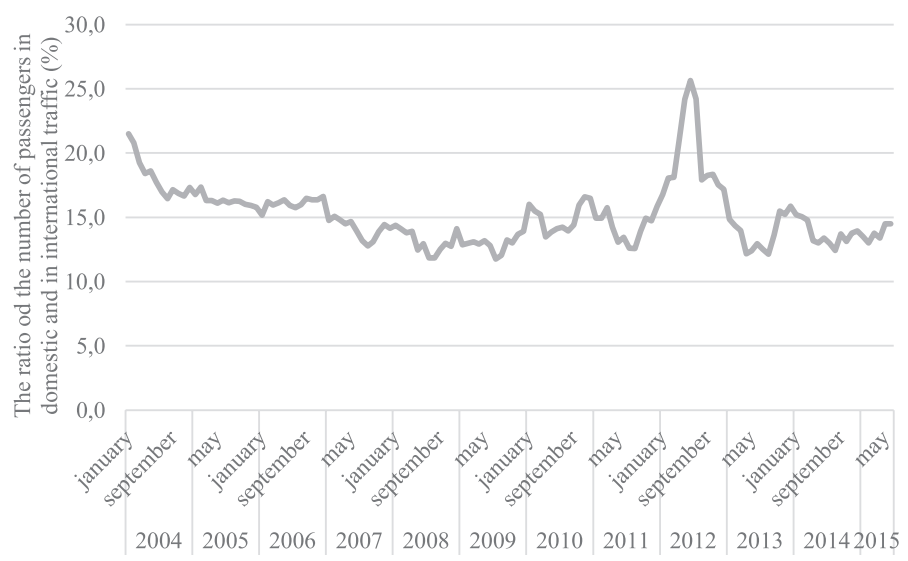

Figure 5. The number of passengers exchanged with Heathrow, Charles de Gaulle and Frankfurt Airport Source: own calculations based on Eurostat data.

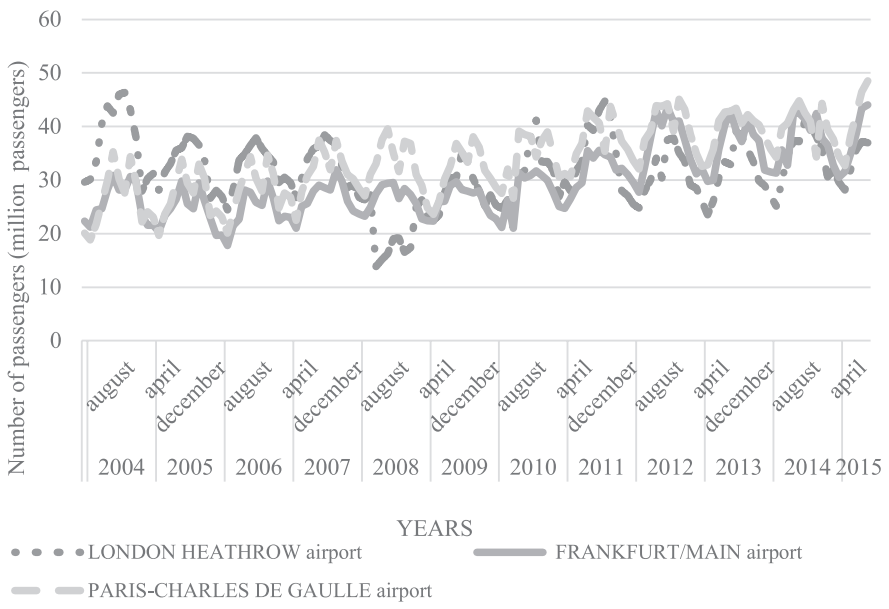

Figure 6. The monthly average of the passengers exchanged with the airports Heathrow, Charles de Gaulle and Frankfurt Airport in the years 2004-2014

Source: own calculations based on Eurostat data.

In order to understand the trend of changes during a year, the monthly average for the years 2004-2014 is presented in figure 6. It can be observed that for connections to the airport in Paris, there has been a nearly 10\% drop in the number of supported passengers in August compared to July and September. A similar downward trend was noted for the connections to the airports in Frankfurt. On the basis of these three airports, an increase in the number of passengers can be observed only in connections to the airport in London in the summer months.

The second analyzed group were "holidays" directions, represented by the Hurghada airport in Egypt and Ben Gurion airport in Tel-Aviv. It can be seen that the number of travelling passengers as a function of time indicates the seasonal changes. The number of passengers as a function 
of months is presented in figure 7. It can be observed that the number of exchanged passengers was significantly higher for Hurghada Airport in 2010 than in other years. Figure 7 can provide the conclusion that the months with highest numbers of exchanged passengers are July-August and March/October for Hurghada Airport and Ben Gurion Airport, respectively.

The confirmation of this observation is presented in fig. 8, which demonstrates the number of passengers handled in these directions in a percentage scale for the average number of people in a given month. It can be assumed that such behavior is due to the fact that some people go on holiday in June (after the end of a school year) and come back in July. As regards the connections to the airport in Tel Aviv, it can be observed that in April/March (Easter) and October (good weather for sightseeing) (U.S. News..., 2016).

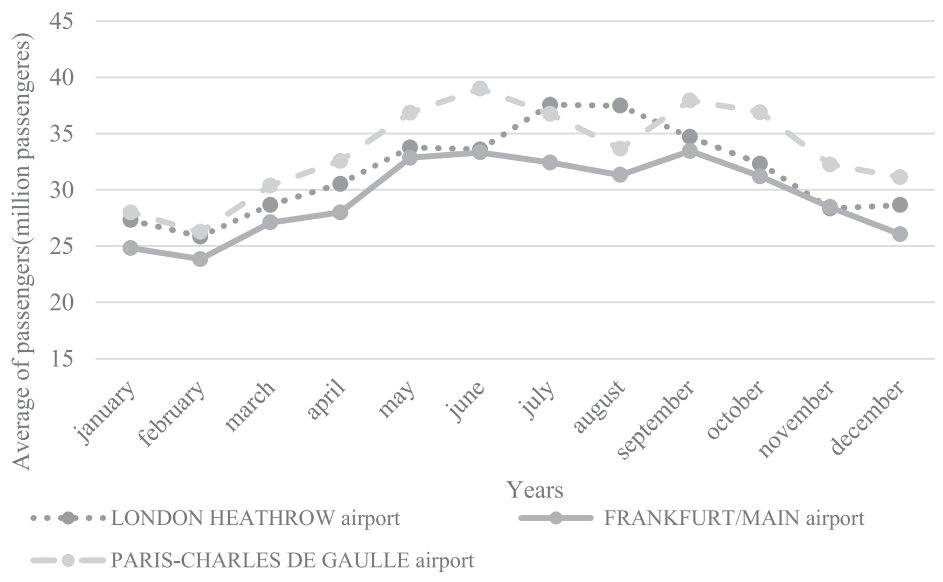

Figure 7. The number of passengers exchanged with airports in Hurghada and Tel-Aviv Source: own calculations based on Eurostat data.

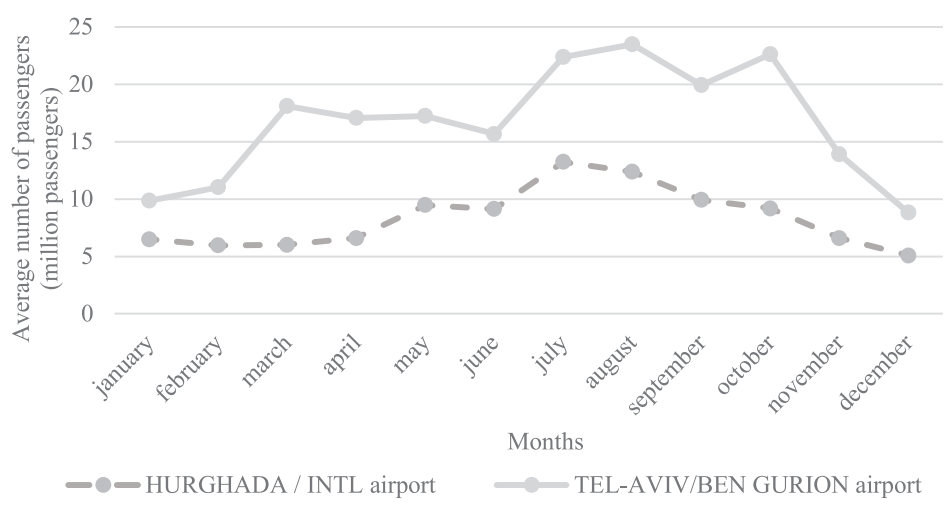

Figure 8. The monthly average of passengers exchanged with airports in Hurghada and in Tel-Aviv in the years 2004-2014.

Source: own calculations based on Eurostat data. 
The third case study is the exchange of passengers between the Chopin Airport and domestic airports. Figure 9 shows the number of passengers handled at the Chopin Airport in domestic traffic. Similar trends and a similar number of served passengers can be seen from the cities of Kraków, Gdańsk, Wrocław, and fewer people from Poznań.

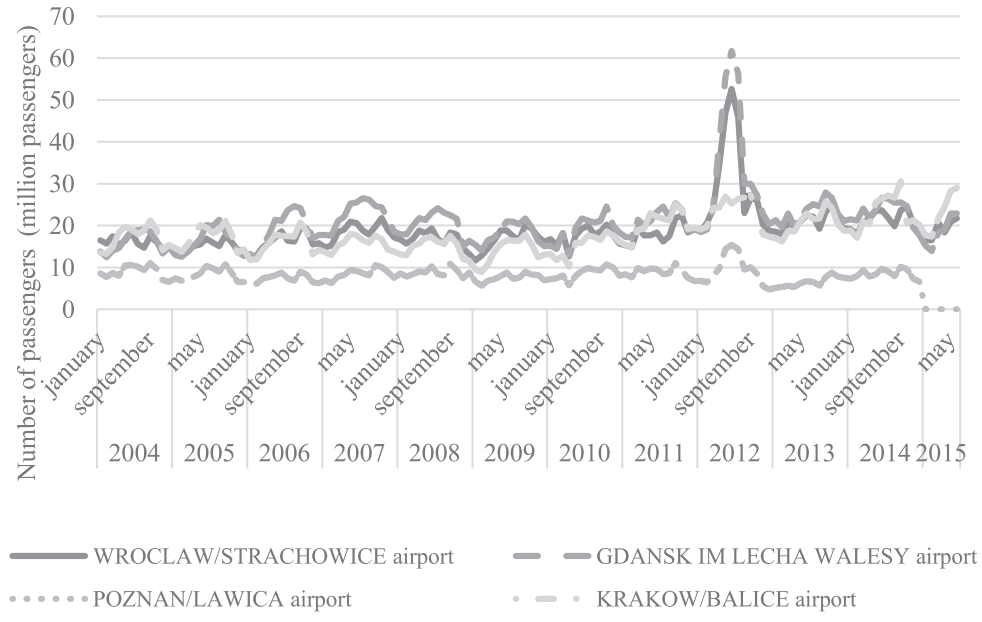

Figure 9. The number of passengers exchanged with domestics airports Source: own calculations based on Eurostat data.

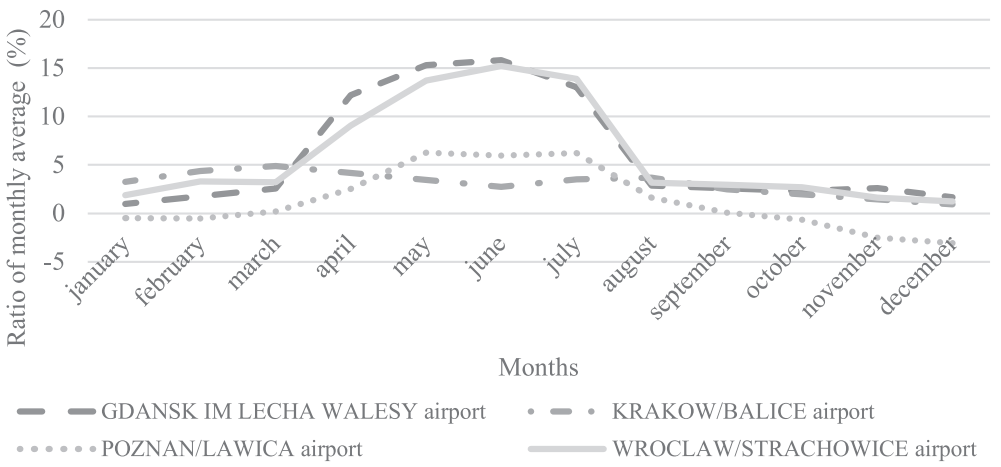

Figure 10. The ratio of the average of passengers between Chopin Airport and domestic airports: Gdańsk, Kraków, Poznań, Wrocław including the year 2012 to a monthly without 2012

Source: own calculations based on Eurostat data.

As concerns figure 9, it can be noticed that large sporting or cultural events cause a significant overstatement of a number of passengers not only in the month in which they take place but also in the months preceding them. Figure 10 presents the ratio of the average with regard to 2012 to the monthly average without this year. As it was concluded before, a significant influence of sport events on the number of travelling passengers has been observed. 


\section{CONCLUSION}

Statistical analysis of the number of passengers handled by the Frederic Chopin Airport shows that there is an upward trend as a function of the subsequent years. It was observed that in order to obtain more accurate analysis, different trends per month have to be taken into account, because of the popularity of the number of passengers, which will affect the character of the place: tourist, business or business-tourism.

\section{REFERENCES}

CNBC. (2011). Worlds Most Popular Business Cities. Retrieved from http://www.cnbc.com/2011/08/15/ Worlds-Most-Popular-Business-Cities.html.

Eurostat. (2016). Eurostat. Retrieved from Eurostat: http://ec.europa.eu/eurostat.

Gruszczyński, M., Podgórska, M. (2008). Ekonometria. Warszawa: Szkoła Główna Handlowa - Oficyna Wydawnicza.

Ptak-Chmielewska, A. (2013). Uogólnione modele liniowe. Warszawa: Oficyna SGH.

Rocznica Lotniska Chopina - Aktualności i wydarzenia - Lotnisko Chopina w Warszawie. (2016). Retrieved from Rocznica Lotniska Chopina - Aktualności i wydarzenia - Lotnisko Chopina w Warszawie: http://www.lotnisko-chopina.pl/pl/aktualnosci-i-wydarzenia/0/305/szczegoly.html.

Smith, N. (2010). Linear Regression using Excel. Retrieved from Linear Regression using Excel: https://it.usu. edu/plugins/work/sitemaps/107/files/Linear_Regression_using_Excel.pdf.

U.S. News \& World Report L.P. (2016). Best Times to Visit Tel Aviv. (Usnews) Retrieved from http://travel. usnews.com/Tel_Aviv_Israel/When_To_Visit/.

Wikipedia. (2010). Air travel disruption after the 2010 Eyjafjallajökull eruption. Retrieved 2017, from https:// en.wikipedia.org/wiki/Air_travel_disruption_after_the_2010_Eyjafjallaj\%C3\%B6kull_eruption.

Analiza ruchu pasażerskiego na lotnisku im. Fryderyka Chopina za pomocą metod statystycznych

STRESZCZENIE W artykule opisano trzy kierunki ruchu pasażerskiego na lotnisku Chopina w Warszawie. W artykule wykorzystano metody statystyczne w celu zaprezentowania głównych trendów w przemieszczaniu się pasażerów zarówno w trakcie roku kalendarzowego, jak również w latach 2004-2015. W pracy przedstawiono zaobserwowane przemieszczanie się pasażerów pomiędzy Warszawą a kierunkami uznawanymi za biznesowe, wakacyjne oraz pomiędzy lotniskami w Polsce. Zaobserwowano, że trendy miesięczne są uzależnione od rodzaju kierunku. W artykule skupiono się na pokazaniu trendów zmian, a nie na ich interpretacji z punktu widzenia geopolitycznego.

SŁOWA KLUCZOWE analiza statystyczna, ruch pasażerski, lotnisko im. Fryderyka Chopina, główne kierunki przemieszczenia. 